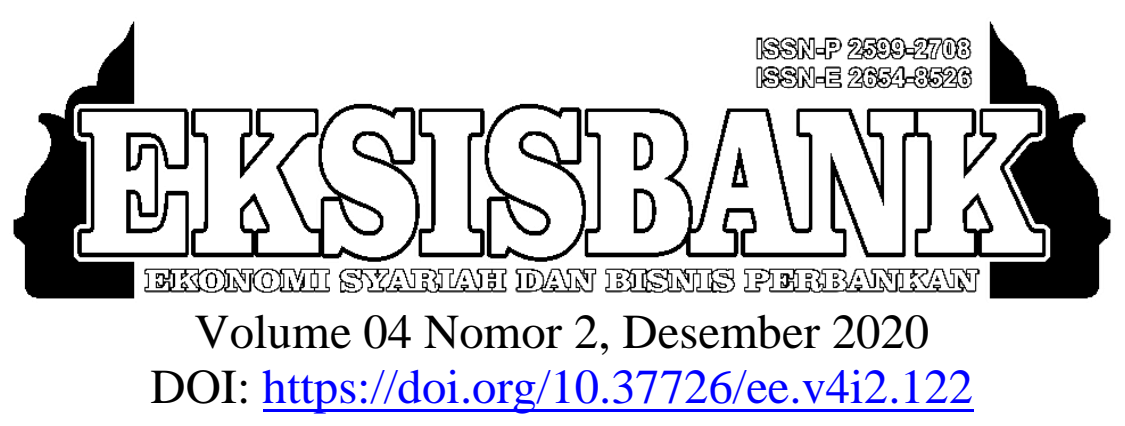

\title{
Implementasi Akad Murabahah Dan Rahn Pada Produk Cicil Emas Di Bank Syari'ah Mandiri Kantor Cabang Pembantu Subang
}

\author{
Ai Siti Nurjadidah ${ }^{1}$, Jalaludin ${ }^{2}$, Ahmad Damiri $^{3}$ \\ ${ }^{1}$ Sekolah Tinggi Agama Islam (STAI) Riyadhul Jannah Subang \\ ${ }^{2}$ Sekolah Tinggi Ilmu Ekonomi Syariah (STIES) Indonesia Purwakarta \\ ${ }^{3}$ Universitas Islam Negeri Sunan Gunung Djati Bandung \\ 1aijadidah05@gmail.com \\ 2jalaludin@sties-purwakarta.ac.id \\ 3ahmad.damiri86@gmail.com
}

\begin{abstract}
ABSTRAK
Investasi emas merupakan investasi yang relatif aman. Emas banyak dipergunakan sebagai standar keuangan di berbagai negeri di dunia, investasi emas berupa logam mulia adalah investasi yang paling mudah dikarenakan dapat digunakan sebagai pelindung nilai saat kritis, Namun untuk melakukan invetasi logam mulia, investor memerlukan biaya awal yang tidak sedikit. Guna mengatasi masalah tersebut bank syariah meluncurkan produk cicil emas dimana para nasabah dapat membeli emas secara cicil melalui bank syariah. Penelitian bertujuan untuk mengetahui sistem akad murabahah dan akad Rahn pada produk pembiayaan Cicil Emas, implementasi akad pembiayaan murabahah dan akad rahn pada produk pembiayaan Cicil Emas di Bank Syari'ah Mandiri KCP Subang dan Manfaat pelaksanaan akad murabahah dan rahn dalam produk pembiayaan cicil emas di Bank Syari'ah Mandiri KCP Subang tahun 2019 metode deskriptif dengan jenis data kualitatif. Teknik pengumpulan data dilakukan dengan pengamatan, wawancara, dan studi dokumentasi. Adapun sumber primernya adalah para pegawai BSM KCP Subang, dan dokumen BSM KCP Subang yang berhubungan dengan pembayaan Cicil Emas. Data sekundernya berupa buku-buku tentang ekonomi syari'ah, internet, dan data lainnya yang mendukung skripsi ini. Hasil penelitian menunjukan bahwa pengimplentasian sistem produk cicil emas di BSM KCP Subang sudah sesuai dengan syari'at ajaran islam. Permasalahan yang terjadi adalah kurangnya promosi atau sosialisasi yang diadakan oleh pihak BSM mengenai produk cicil emas ini.
\end{abstract}

Kata kunci - Akad Murabahah, Akad Rahn, Cicil Emas. 


\begin{abstract}
Gold investment is a relatively safe investment. Gold is widely used as a financial standard in various countries in the world, gold investment in the form of precious metals is the easiest investment because it can be used as a hedge at critical times. However, to invest in precious metals, investors require a large initial fee. In order to overcome this problem, Islamic banks launched a gold installment product where customers can buy gold in installments through Islamic banks. The research aims to determine the murabahah contract system and the Rahn contract on the Gold installment financing product, the implementation of the Murabahah and Rahn financing contract on the Gold Installment financing product at Bank Syari'ah Mandiri KCP Subang and the benefits of implementing the murabahah and rahn contract in gold installment financing products at the Bank. Syari'ah Mandiri KCP Subang in 2019 descriptive method with qualitative data types. Data collection techniques were carried out by observation, interviews, and documentation study. The primary sources are employees of BSM KCP Subang, and BSM KCP Subang documents relating to the financing of the Gold Installment. Secondary data is in the form of books on Islamic economics, the internet, and other data that supports this thesis. The results showed that the implementation of the gold installment product system in BSM KCP Subang was in accordance with Islamic teachings. The problem that occurs is the lack of promotion or socialization held by BSM regarding this gold installment product.
\end{abstract}

Keywords - Murabahah contract, Rahn contract, Gold installment.

\section{PENDAHULUAN}

Emas tidak terpengaruh oleh tingkat inflasi ataupun kebijakan moneter pemerintah. Bahkan ketika terjadi krisis ekonomi, harga emas cenderung baik. Dan keadaan ekonomi mulai membaik, harga emas juga cenderung stabil. Harga emas dari tahun ke tahun selalu mengalami kenaikan (Azmy, 2014; Sihono \& Yusof, 2012). Hal ini dikarenakan persediaan emas di perut bumi sangat terbatas. Emas adalah bahan tambang yang jumlahnya semakin lama akan semakin berkurang, sedangkan permintaan emas semakin bertambah. Itulah yang menyebabkan harga emas dari tahun ke tahun mengalami kenaikan. Grafik 1.1

Peluang Investasi Emas Jangka Panjang Melalui Produk Pembiayaan Bank Syariah

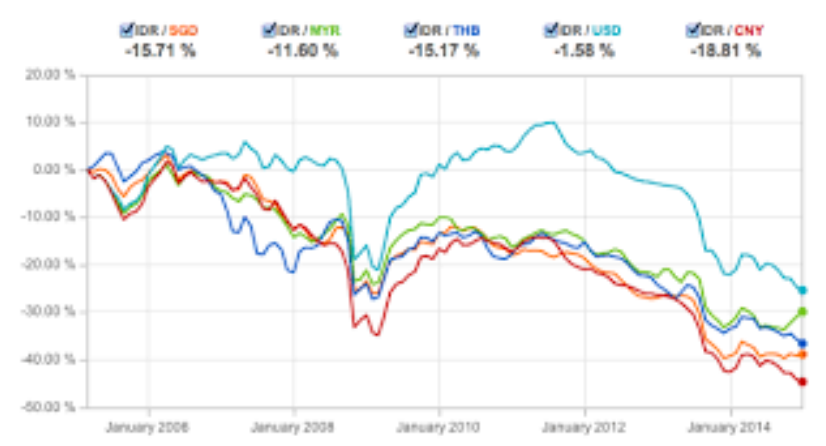

Sumber: (Fauziah \& Surya, 2016)

Investasi emas merupakan investasi yang relatif aman. Emas banyak dipergunakan sebagai standar keuangan di berbagai negeri di dunia dan emas juga dapat digunakan sebagai perhiasan serta cadangan devisa (Yustina, 2013). Investasi emas berupa logam mulia adalah investasi yang paling mudah dikarenakan dapat digunakan sebagai pelindung nilai saat kritis (Tanuwidjaja, 2009). Namun untuk melakukan invetasi logam mulia, investor memerlukan biaya awal yang tidak sedikit. Guna mengatasi masalah 
tersebut bank syariah meluncurkan produk cicil emas dimana para nasabah dapat membeli emas secara cicil melalui bank syariah Mandiri dengan menggunakan skema murabahah.

\section{Grafik 1.2}

Perkembangan Harga Emas Tahun 20122020

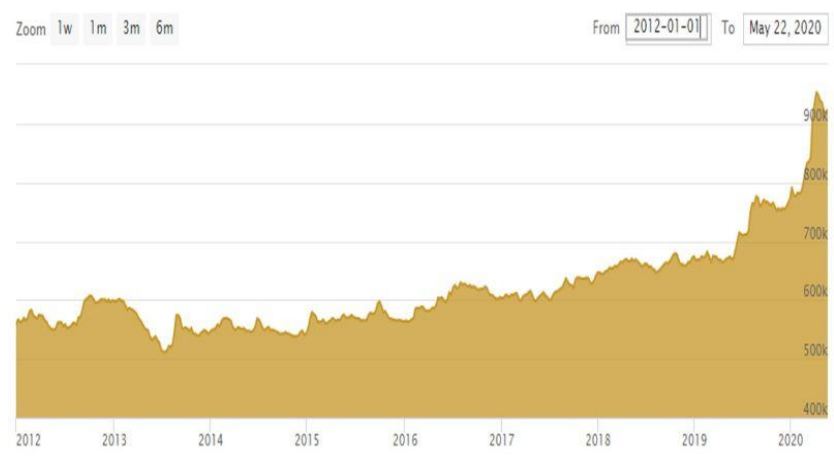

Sumber : (Ulfah, 2020)

Berdasarkan latar belakang diatas, maka dapat diambil pokok permasalahan dari Tugas Akhir ini bahwa kurangnya pengetahuan dan pemahaman masyarakat pada investasi yang menguntungkan. Kemudian yang dijadikan fokus pemaparan adalah mengenai produk yang ada di Bank Syari'ah Mandiri Kantor Cabang Pembantu Subang mengenai Cicil Emas dengan mengguanakan akad Murabahah dan Rahn, untuk memastikan produk tersebut sesuai dengan syariat islam atau tidaknya. Dengan begitu akan lebih leluasa dan akan memberikan kemaslahatan kepada nasabah yang menggunakan produk tersebut.

Dalam prakteknya di Bank Syari'ah Mandiri KCP Subang, ketika akad murabahah terjadi emas yang dibeli nasabah secara dicicil masih berada ditangan supplier dengan status emas tersebut belum dibeli secara sah oleh bank, kemudian emas tersebut langsung dijadikan jaminan atas utang cicil emas nasabah dimana jaminannya tersebut diikat dengan akad Rahn. Hal ini terjadi dalam pembiayaan cicil emas ini adalah emas yang menjadi objek pembiayaannya belum menjadi milik nasabah. Karena dalam pembiayaan jual-beli, bank bertindak sebagai penjual dan nasabah sebagai pembeli. Dengan kata lain nasabah menggadaikan barang yang bukan milikinya sendiri karena barang yang digadaikan adalah objek pembiayaan antara bank dan nasabah.

Akad transaksi pada era masa kini tentunya mengalami perubahan karena harus menyesuaikan diri dengan kebutuhan masyarakat sekarang. Konsekuensinya, tidak jarang beberapa jenis transansi hukumnya dipertanyakan lagi, apakah jenis transaksi ini sesuai dengan syari'ah atau tidak. Karena pada dasarnya, akad memiliki rukun dan syarat yang harus terpenuhi. Namun, karena telah menjadi adat kebiasaan dalam masyarakat sebagian umat islam, adat kebiasaan yang berlaku dalam suatu masyarakat yang membawa maslahat yang dapat dibenarkna sebagai landasan dalam menetapkan suatu hukum.

Pembiayaan cicil emas merupakan produk terbaru dari Bank Syari'ah, dimana praktik diperbankan produk ini membantu nasabah untuk memiliki emas batangan dengan cara mencicil. Dalam praktek akad yang digunakan pada produk ini adalah murabahah dengan jaminan yang diikat oleh akad rahn (Renny Tri Setiani, 2018; Zaenuri, 2014).

Pembiayaan murabahah yang ada di bank syari'ah merupakan perjanjian jual beli antara bank dan nasabah dimana bank syari'ah membeli barang yang diperlukan oleh nasabah dan kemudian menjualnya kepada nasabah yang bersangkutan sebasar harga perolehan ditambah margin (keuntungan) yang disepakati antara bank dan nasabah (Rival \& Ismail, 2013).

Dari pengertian murabahah di atas dapat dikemukakan bahwa inti dari jual beli murabahah adalah penjual mendapatkan manfaat keuntungan dan pembeli mendapat 
manfaat dari benda yang dia beli. Karena dalam definisi tersebut adanya "keuntungan yang disepakati", karakteristik murabahah adalah si penjual harus memberi tahu pembeli tentang harga pembelian barang dan menyatakan jumlah keuntungan yang ditambahkan pada biaya tersebut.

Berdasarkan pemaparan diatas, mendorong penulis untuk meneliti lebih lanjut bagaimana pelaksanaan cicil emas di Bank Syari'ah Mandiri, sehingga penulis tertarik melakukan penelitian dalam sebuah skripsi yang berjudul "Implementasi akad Murabahah dan Rahn pada produk pembiayaan cicil emas di Bank Syari'ah Mandiri KCP Subang”.

Adapun tujuan yang ingin dicapai oleh penulis dalam penulisan ini adalah Untuk mengetahui sistem pembiayaan akad Murabahah dan Rahn pada pembiayaan cicil emas; Untuk mengetahui Implementasi akad Murabahah dan Rahn dalam produk pembiayaan cicil emas di Bank Syari'ah Mandiri KCP Subang; Untuk mengetahui manfaat pelaksanaannya cicil emas di Bank Syari'ah Mandiri KCP Subang.

\section{TINJAUAN PUSTAKA}

Penelitian tentang Implementasi Akad Murabahah Dan Rahn Pada Produk Cicil Emas sudah banyak dilakukan oleh peneliti sebelumnya, tapi tentu saja mempunyai perbedaan-perbedaan antara penelitian ini dengan penelitian sebelumnya. Berikut adalah penelitian sebelumnya yang meneliti tentang Implementasi Akad Murabahah Dan Rahn Pada Produk Cicil Emas Di Bank Syari'ah Mandiri Kantor Cabang Pembantu Subang;

1.Penerapan Akad Murabahah Dalam Produk Gadai Emas Bank Syariah Mandiri (BSM)

Di Kantor Cabang Sleman (Renny Tri Setiani, 2018)

Analisis penerapan akad murabahah pada produk BSM Cicil Emas Pada prinsipnya produk cicil emas yang dikeluarkan oleh Bank
Syariah Mandiri diperuntukkan kepada masyarakat yang ingin memiliki emas Namun tidak cukup dalam hal pendanaan, maka bank syariah memiliki inisiatif untuk mengeluarkan produk cicil emas dengan cara angsuran. Prosedur pembiayaan pada produk BSM cicil emas yang dikeluarkan oleh Bank Syariah Mandiri cabang Sleman menggunakan dua akad, yaitu akad Murabahah dan akad Rahn. Akad Murabahah terjadi antara pihak nasabah dengan pihak lembaga perbankan syariah dalam hal pembelian cicilan emas, dimana bank memberitahukan jumlah keuntungan yang diperoleh bank atas pembelian barang yang diminta nasabah, disamping itu untuk pengikatan jaminannya bank mengikatkan emas tersebut sebagai jaminan atas pembiayaan emas itu sendiri dengan menggunakan akad Murabahah dan akad Rahn.

\section{Multiakad Murabahah Dan Rahn Pada} Produk Logam Mulia Perspektif Hukum Ekonomi Syariah Studi Kasus Pada PT. Pegadaian (Persero) Unit Pelayanan Syariah Alianyang Singkawang (Hatoli \& Parwanti, 2020)

Operasional setiap lembaga keuangan yang berbasis syariah secara yuridis harus merujuk kepada fatwa DSN-MUI, tidak terkecuali masalah multiakad atau lebih dikenal dengan hybrid contract. Dimana hal ini telah diamanatkan oleh UU No.21 Tahun 2008 tentang Perbankan Syariah Pasal 26 ayat (2). Di dalam fatwanya, terdapat dua multiakad yang diperbolehkan oleh DSN-MUI, yaitu Fatwa No. 71 Tahun 2008 tentang Sale and Lease Back dan Fatwa No. 72 Tahun. 2008 tentang Ijarah Sale and Back. Namun PT. Pegadaian (Persero) Unit Pelayanan Syariah Alianyang Singkawang telah melaksanakan multiakad (murabahah dan rahn) sejak 6 (enam) tahun terakhir pada produk Murabahah Logam Mulia Investasi Abadi 
(MULIA) pembiayaan emas secara tidak tunai, dimana hal ini belum ada fatwanya dari DSNMUI, sehingga memunculkan keraguan akan jaminan kesyariahan dari produk tersebut. Maka menjadi penting dikaji tentang bagaimana sistem akad produk MULIA yang menggunakan akad murabahah dan rahn dari perspektif hukum ekonomi syariah. Penelitian ini merupakan penelitian kualitatif yang bercorak deskriptif yang diperdalam dengan cara melakukan wawancara secara langsung kepada pihak yang terlibat dalam penerapan multiakad murabahah dan rahn ini. Hasil penelitian menyimpulkan bahwa penerapan multiakad murabahah dan rahn pada produk logam mulia di PT. Pegadaian (Persero) Unit Pelayanan Syariah Alianyang Singkawang sebagaimana yang tertuang dalam Undangundang No. 21 Tahun 2008 tentang perbankan syariah sudah dijalankan pada produk tersebut, serta dalam pandangan hukum ekonomi syariah adalah boleh dan dibenarkan, karena sistemnya merujuk kepada fatwa DSN-MUI No. 92 tahun 2014 tentang pembiayaan yang disertai rahn dan menjadi dasar dalam penggunaan multiakad.

\section{Penerapan Akad Murabahah pada Produk MULIA di Pegadaian Jalancagak Menurut Perspektif Ekonomi Syariah (Meirani et al., 2020)}

Penelitian ini dilaksanakan di Pegadaian Jalancagak Kabupaten Subang. Pegadaian adalah salah satu lembaga keuangan yang menawarkan jasa investasi Logam Mulia yang salah satu produknya dinamakan MULIA (Murabahah Logam Mulia Untuk investasi Abadi). Produk Mulia merupakan penawaran pembiayaan kepada nasabah untuk pembelian Emas batang yang di produksi oleh PT. Aneka Tambang (ANTAM). Penelitian ini bertujuan untuk mengetahui bagaimana ketentuan produk MULIA, penerapan akad Murabahah pada produk MULIA serta dampak produk MULIA bagi pegadaian dan masyarakat. Jenis penelitian ini adalah kualitatif dengan menggunakan metode deskriptif analisis. Sumber data yang digunakan meliputi data primer dan sekunder. Dari hasil pembahasan peneliti mendapatkan ada beberapa ketentuan dalam penerapan akad Murabahah produk MULIA di Pegadaian Jalancagak yang belum sesuai dengan ketentuan syariat, diantaranya; pertama mengenai Objek akad atau Marhun yang tidak dimunculkan atau tidak ada ketika akad berlangsung. Kedua, mengenai sanksi yang dibolehkan menurut syariat adalah berlaku untuk nasabah yang mampu tapi lalai atau menunda nunda pembayaran tapi tidak berlaku untuk nasabah yang benar-benar tidak mampu membayar, namun dalam penerapannya di pegadaian Jalancagak mengharuskan semua nasabah menerima sanksi atau membayar denda apabila tidak mampu membayar tanpa kecuali. Ketiga, dalam penerapan sanksi/denda mengenai dana yang dihasilkan dari denda di masukan sebagai pendapatan Perusahaan, yang secara ketentuan syariat seharusnya diperuntukan untuk dana social.

\section{Analisis Fatwa SDN-MUI No.77 / DSN} MUI / V / 2010 Tentang Cicil Emas Akad Murabahah Pada Produk Cicil Emas Di Bank Syariah Mandiri (BSM) KCP Surapati (Mulyani et al., 2017)

Dalam pelaksanaannya salah satu produk bank syariah yang diminati nasabah adalah produk cicil emas yang dalam pelaksaannya menggunakan akad murabahah. Salah satu bank syariah yang mengeluarkan produk tersebut adalah Bank Syariah Mandiri KCP Surapati. Dalam pelaksaannya, Bank Syariah Mandiri menetapkan besaran cicilanya sesuai dengan yang disepakati dengan nasabahserta mengabaikan fuktuasi harga emas di pasar. Artinya, ketika harga pasar emas naik tidak 
memyebabkan harga cicilan naik. Di sisi lain, terdapat Fatwa DSN MUI NO:77/DSNMUI/V/2010 tentang jual beli emas secara tidak tunai, terkait hal tersebut masalah dan tujuan yang ingin di teliti adalah ketentuan Fatwa DSN MUI NO:77/DSN-MUI/V/2010 tentang jual beli emas secara tidak tunai, pelaksaan cicil emas dengan akad murabahah di BSM, analisa Fatwa DSN MUI NO:77/DSN-MUI/V/2010 terhadap cicil emas di BSM.Metode penelitian yang digunakan adalah deskriptif analitis, dengan pendekatannya dengan analitis kualitatif dan teknik pengumpulan data adalah wawancara dan studi kepustakaan.Hasil penelitian menunjukan bahwa ketentuan Fatwa DSN MUI NO:77/DSN-MUI/V/2010 jual beli emas secara tidak tunai harus harga jual (tsaman) tidak boleh bertambah selama jangka waktu perjanjian meskipun ada perpanjangan waktu setelah jatuh tempo. Emas yang dibeli dengan pembayaran tidak tunai boleh dijadikan jaminan (rahn). Emas yang dijadikan jaminan sebagaimana dimaksud dalam angka 2 tidak boleh dijualBelikan atau dijadikan obyek akad lain yang menyebabkan perpindahan kepemilikan. Pelaksanaan cicil emas di BSM KCP Surapati pada dasarnya bank menjelaskan prosedur pembiayaan akad murabahah, hanya saja penentuan margin bukan atas dasar kesepakatan yang terjadi antara nasabah dan penjual (bank) namun sudah menjadi ketetapan pihak bank terlebih dahulu yang kemudian ditawarkan kepada nasabah. Dengan itu seharusnya pihak Bank menentukan besaran margin diawal dengan berdasarkan kesepakatan. Analisa Fatwa DSN MUI NO:77 /DSN-MUI/0V/2010 terhadap pelaksaan pembiayaan cicil emas BSM KCP Surapati sudah sesuai.

\section{Analisis Pembiayaan Murabahah Cicil} Emas Pada Bank Syariah Mandiri Cabang Pontianak (Dwi Nurul Hasnawati, 2018)

Pada masa sekarang, jenis investasi ini semakin dilirik oleh masyarakat umum terlebih dalam bentuk emas batangan maupun koin emas, ada beberapa cara yang dapat dipilih oleh masyarakat untuk dapat memiliki investasi berbentuk emas batangan tanpa membeli secara kontan, Salah satunya adalah membeli emas dengan dana pinjaman atau dengan membeli emas dengan sistem mencicil. Dengan mengacu pada pertumbuhan ekonomi yang semakin meningkat, dimana setiap lapisan masyarakat banyak melakukan investasi disegala bidang. Bank Syariah Mandiri membaca peluang tersebut dengan menghadirkan Produk Cicil Emas Bank Syariah Mandiri. BSM Cicil Emas adalah fasilitas yang disediakan oleh Bank Syariah Mandiri untuk membantu nasabah untuk membiayai pembelian/kepemilikan emas berupa lantakan (batangan) dengan Cara Mudah Punya Emas dan Menguntungkan. Jenis emas yang dapat dibiayai adalah Emas lantakan (batangan) dengan minimal jumlah gram adalah 10 gram. Dan emas ini yang kemudian akan dijadikan sebagai jaminan pembiayaan Cicil Emas BSM tersebut. yang dimaksud dengan jaminan adalah barang yang menjadi objek pembiayaan (emas) dan Jaminan ini tidak dapat ditukar agunan lain, pengikatan jaminan dilakukan selama masa pembiayaan kemudian fisik jaminan disimpan di Bank. Metode Penelitian ini adalah bersifat deskriptif analitis. Penelitian deskriptip adalah studi untuk menemukan fakta dengan interpretasi yang tepat. Sedangkan pendekatan analitis ditujukan untuk menguji mengadakan interpretasi yang lebih mendalam tentang hubungan-hubungan. Hasil penelitian Cara pembayaran produk BSM Cicil Emas ini pembayarannya dilakukan dengan cara angsuran dalam jumlah yang 
sama setiap bulan dengan jangka lama jangka waktu pembiayaan BSM Cicil Emas dapat dipilih sendiri oleh nasabah dengan memilih angka waktu pembiayaan yang diinginkan paling singkat 2 (dua) tahun dan paling lama hingga 5 (lima) tahun. Akad / pengikat yang digunakan untuk produk BSM Cicil Emas Pembiayaan menggunakan akad Murabahah (di bawah tangan). Pengikatan agunan dengan menggunakan akad rahn (gadai).

\section{Pandangan Ekonomi Islam Tentang} Investasi Murabahah Logam Mulia (Studi pada Cabang Pegadaian Syariah Istiqlal Manado) (Kasim, 2016)

Penelitian ini bertujuan untuk mengetahui bagaimana pandangan ekonomi Islam tentang investasi murabahah logam mulia di Cabang Pegadaian Syariah Istiqlal Manado. Penulis menemukan bahwa peoses transaksi murabahah melalui logam mulia untuk investasi abadi (MULIA) pada Cabang Pegadaian Syariah Istiqlal Manado dimulai dari transaksi pemesanan, transaksi pembelian ke pemasok kemusian transaksi pembayaran dan pelunasan. Akad yang selama ini digunakan oleh Pegadaian Syariah terhadap barang jaminan (marhun) adalah wadiah alamanah, sebab barang yang dijadikan agunan/jaminan disimpan rapi dan diperkenankan membuka segel bagi penerima titipan sampai pemberi titipan atau pemberi gadai (rahin) mengambilnya. Hal tersebut dilakukan untuk menjaga keamanan terhadap barang jaminan. Pandangan hokum ekonomi Islam terhadap investasi logam mulia pada Pegadaian Syariah Istiqlal Manado dibolehkan sebab sistem yang digunakan sama dengan sistem pegadaian yaitu melakukan kesepakatan atau akad dan tidak membebani kedua pihak dan melakukan kontrak yang sah tanpa ada paksaan dan penipuan. Persyaratan dan prosedur pemberian pinjaman atau pembiayaan telah ditentukan oleh pegadaian syariah berdasarkan kaidah-kaidah Hukum Islam: persyaratan sederhana, prosedur mudah, akad secara tertulis, pembiayaan/hutang dengan jaminan berang yang sudah dibeli, tidak dipungut bunga, keuntungan/margin dan isi perjanjian ditentukan oleh kedua belah pihak serta pembiayaan tidak mengandung gharar.

\section{Analisis Pengaruh Pendanaan Murabahah,} Mudharabah, Musyarakah, Dan Rahn (Pawning) Emas Terhadap Laba Bersih Pt Bank Syariah Mandiri (BSM), Tbk. (Maulidiyah \& Susyanti, 2017)

Tujuan dari penelitian ini adalah untuk menganalisis pengaruh pembiayaan murabahah, mudharabah, musyarakah, dan rahn (gadai) emas terhadap laba bersih PT Bank Syariah Mandiri (BSM), Tbk. Penelitian ini merupakan studi kasus dengan objek penelitian PT Bank Syariah Mandiri (BSM), Tbk. Pengumpulan data menggunakan metode dokumentasi dengan mengumpulkan laporan keuangan tahun 2012-2015, sedangkan metode analisisnya menggunakan analisis regresi berganda. Hasil penelitian ini adalah pendanaan murabahah berpengaruh positif dan signifikan terhadap laba bersih, pendanaan mudharabah berpengaruh positif dan tidak signifikan terhadap laba bersih, pendanaan musyarakah berpengaruh negatif dan signifikan terhadap laba bersih, dan rahn pendanaan emas berpengaruh positif dan signifikan terhadap laba bersih. laba bersih.

8. Transaksi Pembelian Emas Non Riil Di PT. Pegadaian Syariah KCP Darussalam Dalam Perspektif Akad Ba'i Al-Muqayyad (Studi Tentang Cicilan Emas Dan Konsekuensinya Pada Tabungan Emas) (Seroja \& Iqbal, 2020)

Produk Tabungan emas PT. Pegadaian Syariah ini menggunakan sistem beli dan titip emas, Emas yang dijual oleh pihak pegadaian 
adalah bentuk emas non riil, maka pada saat pembelian emas nasabah tidak langsung mendapatkan emasnya, dalam hal ini nasabah hanya melihat nilai tabungan melalui saldo rekening pada tabungan emas, sedangkan emas hanya diketahui dalam bentuk nilainya saja karena fisik emas belum diserahkan sampai lunas harganya dan emas yang dicicil dititipkan pada PT. Pegadaian Syariah. Berdasarkan uraian latar belakang masalah di atas, maka rumusan masalah yang penulis ambil yaitu: Bagaimana Penentuan harga, cost penitipan dan biaya transaksi pada jual beli emas secara non cash di PT. Pegadaian Syariah KCP Darussalam?; Bagaimana konsekuensi bagi para pihak dalam transaksi jual beli emas bersyarat?; serta Bagaimana keabsahan jual beli emas pada produk tabungan emas di PT. Pegadaian Syariah KCP Darussalam dalam perspektif akad ba ${ }^{\text {ee }}$ almuqayyad?.

Metode penelitian yang digunakan adalah metode kualitatif yang menitikberatkan pada pengumpulan data dokumentasi, untuk menyempurnakan data dokumentasi penulis juga membutuhkan data wawancara. Setelah melakukan analisa mendalam terhadap fokus penelitian penulis dapat menyimpulkan Dilihat dari perspektif akad ba ${ }^{e i}$ almuqayyad, jual beli emas pada produk tabungan emas di PT. Pegadaian Syariah KCP Darussalam ini secara formal sah, karena jual beli yang diikatkan dengan syarat tertentu seperti penitipan diperbolehkan menurut hukum islam, dalam mazhab Hanafiyah syarat yang dimaksud yaitu syarat yang sejalan dengan tujuan transaksi. Sasabah tabungan emas tidak dapat mengambil emasnya sebelum cicilan emas memadai, lalu emasnya harus dititipkan kepada pihak Pegadaian Syariah. Namun, pada hakikatnya tidak ada emas yang disimpan di seluruh outlet PT. Pegadaian Syariah tempat nasabah melakukan transaksi, jika nasabah ingin mengambil emas, emas harus dipesan kepada PT. Antam terlebih dahulu selama \pm seminggu, lalu nasabah dikenakan biaya penitipan sebesar Rp.30.000.

9. Strategi Pemasaran pembiayaan cicilan emas di BSM KCP Dramaga (Yaqin, 2019)

Penelitian ini dirancang untuk menemukan strategi pemasaran produk pembiayaan cicilan emas yang tepat hingga mampu untuk memikat nasabah agar tertarik untuk menggunakan cicilan emas. Penelitian ini menggunakan metode kualitatif yang diperoleh melalui observasi, wawancara, dan penelitian pustaka. Dari hasil analisis yang diperoleh adalah Bank X Syariah KCP Dramaga menerapkan strategi pemasaran dengan menggunakan konsep bauran pemasaran yang bisa dikenal 3P yaitu periklanan, penjualan pribadi, publisitas.Kata Kunci: Strategi pemasaran, metode kualitatif, konsep bauran pemasaran.

\section{Perlakuan Akuntansi Pembiayaan Gadai dan Cicil Emas PT Bank Syariah Mandiri Jember (Rahman et al., 2018)}

Penelitian ini bertujuan untuk mengetahui bagaimana cara mengetahui pembiayaan gadai emas dan kredit emas di PT Bank Syariah kantor cabang Jember. Teknik pengumpulan data dalam penelitian ini adalah data primer dengan wawancara dan Data Sekunder Dari Catatan atau arsip yang berkaitan dengan perlakuan akuntansi pembiayaan emas. dan kredit Emas. Analisis yang digunakan dalam penelitian ini menggunakan analisis deskriptif komparatif kualitatif dengan membandingkan penerapan perlakuan akuntansi pembiayaan gadai emas syariah dan emas kredit dengan PSAK 107 dan PSAK 102. Hasil penelitian ini menunjukkan bahwa perlakuan akuntansi yang meliputi pengakuan, pengukuran , penyajian, pengungkapan pembiayaan gadai emas syariah dan kredit emas telah dengan 
PSAK 107 Akuntansi Ijarah dan PSAK 102, Akuntansi Murrabahah.

\section{METODOLOGI PENELITIAN}

Sumber data dalam penelitian ini terbagi pada dua bagian, yaitu sumber data primer dan sumber data sekunder (Hidayat, 2013; Lestari, 2020). Sumber data primer, yaitu sumber data pokok yang terdiri dari para pengurus Bank Syari'ah Mandiri KCP Subang atau dua orang yang libat langsung di dalam pelaksanaan akad murabahah dan rahn pada produk cicil emas syari'ah dan dokumentasi BSM.

Sumber data sekunder, yaitu sumber data penunjang yang diperoleh dari berbagai referensi seperti penguat, anatara lain didapat dari arsip-arsip, dokumentasi resmi Bank Syari'ah Mandiri KCP Subang serta brosurbrosur, serta berbagai sumber literatur lainnya yang berhubungan dengan masalah yang penulis teliti serat buku-buku yang berkaitan dengan permasalahn yang dianalisis.

Jenis data yang dipergunakan dalam penelitian ini berupa data kualitatif (Hendryadi, 2015). Data kualitatif berupa data hasil wawancara yang dilakukan dengan salah satu karyawan Bank Syari'ah Mandiri KCP Subang khususnya yang mengurus produk cicil emas dan juga data dari buku-buku dan skripsi yang lain.

Teknik pengumpulan data yang digunakan untuk memperoleh data dalam penelitian ini adalah Observasi, yaitu penelitian yang dilakukan dengan cara mengadakan pengamatan langsung di Bank Syari'ah Mandiri KCP Subang seputar masalah pelaksanaan akad murabahah dan akad rahn pada produk cicil emas yang dilaksanakan pada tanggal 15 Maret 2019. (Wawancara pada tanggal 22 Agustus 2019 pukul 10.0011.00 dengan Ibu Ratna Ayudini, selaku Consumer Administration Staff di Bank Syari'ah Mandiri KCP Subang).
Selain Observasi dilakukan juga wawancara pada tanggal 22 Agustus 2019 pukul 10.0011.00 dengan Ibu Ratna Ayudini, selaku Consumer Administration Staff di Bank Syari'ah Mandiri KCP Subang dimana salah satu tugasnya adalah mengurus produk cicil emas.

Selanjutnya, dilakukan juga Studi kepustakaan yang dilakukan penulis dengan membaca, mendalami, dan menelaah berbagai literatur berupa buku-buku dan sumber lain yang dapat digunakan untuk mendukung dan melengkapi penelitian ini serta mengungkapkan teori dan konsep yang terkait dengan penelitian.

Studi dekomuntasi, yaitu mencari data mengenai hal-hal yang variable yang berupa catatan, buku-buku, surat kabar, dan lain-lain yang sesuai dengan masalah yang diteliti.

Pada dasarnya analisis data merupakan pengurai data melalui tahap kategorisasi dan klarifikasi, perbandingan dari pencarian hubungan antara data yang spesifik tentang hubungan antara perubah (Sugiyono, 2018).

Data yang dianalisis adalah data-data yang berkaitan dengan masalah. Data yang sudah terkumpul oleh penulis akan dianalisis dengan menggunakan pendekatan kualitatif. Dalam pelaksaannya, penganalisisan dilakukan dengan langkah-langkah- sebagai berikut :

a. Mengumpulkan data. Langkah ini dilakukan dengan mengumpulkan data dan informasi tentang pelaksanaan akad murabahah dan rahn pada produk cicil emas di Bank Syari'ah Mandiri KCP Subang.

b. Menyeleksi data. Suatu proses dalam melakukan pengelompoka data

c. yang didapatkan dilokasi penelitian, yaitu di Bank Syari'ah Mandiri KCP Subang.

d. Menganalisis data, merupakan tahap dari proses penelitian karena dalam isinya ini terdapat uraian-uraian yang akan 
menjawab permasalahan dalam penelitian ini.

e. Menyimpulkan. Tahap ini merupakan tahap terkahir dalam suatu penelitian dan dari kesimpualn tersebut akan diketahui tentang hasil akhir dari penelitian.

\section{HASIL DAN PEMBAHASAN}

A.Sistem Pembiayaan akad Murabahah dan Rahn pada Pembiayaan Cicil Emas

Dalam hal ini BSM menalangi untuk membeli emas terlebih dahulu sebelum cicilan dari nasabah terlunasi dalam jangka waktu yang sudah ditentukan. Hal itu sudah sesuai dengan salah satu isi fatwa DSN MUI No: 04/DSN-MUI/IV/2000 tentang murabahah yaitu "Nasabah membayar harga barang yang telah disepakati tersebut pada jangka waktu tertentu yang telah disepakati”. Secara hukum Islam, pembiayaan produk BSM Cicil Emas dengan menggunakan akad murabahah diperbolehkan dalam Islam karena dalam transaksi jual beli ini pihak bank menjelaskan kepada nasabah secara jelas perihal harga pokok serta marginnya. Hal ini sebagaimana dijelaskan dalam Fatwa DSN MUI No:04/DSNMUI/IV/2000 tentang murabahah yang salah satu isinya berbunyi "Bank harus menyampaikan semua hal yang berkaitan dengan pembelian, misalnya jika pembelian dilakukan secara utang". Dari wawancara yang dilakukan peneliti dengan Ratna Ayudini selaku Customer Administration Staff BSM Cabang Subang, dalam melaksanakan akad pembiayaan BSM cicil emas, pihak BSM menjelaskan semua proses pembiayaan secara rinci kepada nasabah, dari mulai harga pokok, margin, jangka waktu pembayaran hingga jika terjadi wanprestasi. Hanya saja penentuan margin bukan atas dasar kesepakatan yang terjadi antara nasabah dan penjual namun sudah menjadi ketetapan pihak Bank terlebih dahulu yang kemudian ditawarkan kepada nasabah. Produk BSM
Cicil Emas diperbolehkan karena emas termasuk barang yang boleh diperjual belikan.

Dalam hal pengadaan emas, pihak BSM bekerjasama dengan PT. Antam Persero, toko emas atau perorangan yang telah memiliki kerja sama dengan BSM. Dalam hal ini pihak BSM menyatakan: "Kami dari pihak BSM bekerjasama dengan PT. Antam Persero, toko emas atau perorangan yang telah memiliki kerja sama dengan BSM. Jadi sudah jelas dihalalkan, karena tidak mungkin kami menggunakan jasa yang belum kami periksa sebelumnya. Aspek kehalalan barang yang diperjual belikan menjadi penting karena sebagaimana difatwakan oleh DSN MUI No: 04/DSN-MUI/IV/2000 tentang murabahah menyebutkan bahwa, "Barang yang diperjual belikan tidak diharamkan oleh syari'ah Islam" dan emas tidak termasuk barang yang dikategorikan haram. Dengan demikian produk ini tidak bertentangan dengan fatwa DSN-MUI. Selain akad murabahah, produk BSM Cicil Emas juga menggunakan akad rahn. Akad rahn digunakan sebagai pengikatan agunan atau emas itu sendiri selama masa pencicilan emas berlangsung. Secara umum, pengertian gadai (rahn) yaitu menahan barang jaminan yang bersifat materi milik si peminjam (rahin) sebagai jaminan atas pinjaman yang diterimanya, dan barang yang diterima tersebut bernilai ekonomis, sehingga pihak yang menahan (murtahin) memperoleh jaminan untuk mengambil kembali seluruh atau sebagian utangnya dari barang yang digadaikan, bila pihak yang menggadaikan tidak dapat membayar utang pada waktu yang telah ditentukan maka jaminan tersebut akan diesksekusi. Namun, semua itu tentunya sudah ada kesepakatan terlebih dahulu antara pihak bank dengan nasabah pada saat akad berlangsung.

Dalam pelaksanaan akad rahn pada produk pembiayaan BSM Cicil Emas BSM Cabang Subang berpedoman pada landasan syariah 
yaitu fatwa DSN MUI No: 26/DSNMUI/III/2002 tentang Rahn Emas yang salah satu isinya berbunyi bahwa "akad rahn dibolehkan berdasarkan prinsip rahn". Mekanisme akad rahn dalam pembiayaan BSM Cicil Emas di BSM pihak bank menangguhkan atau menyimpan emas nasabah yang dibelinya selama masa penyicilan berlangsung yaitu dari 1- 5 tahun. Sesuai dengan isi fatwa yang berbunyi "Murtahin (penerima barang) mempunyai hak untuk menahan marhun (barang) sampai semua utang Rahin (yang menyerahkan barang) dilunasi. Mengenai biaya pemeliharaan atau penyimpanan agunan ditanggung oleh rahin atau nasabah yang menggadaikan emasnya. Pada saat akad sudah dijelaskan pula mengenai biayabiayapemeliharaan agunan selama masa pencicilan berlangsung. Hal itu sesuai dengan isi fatwa DSN MUI No: 26/DSNMUI/III/2002 tentang Rahn yang berbunyi "Ongkos dan biaya penyimpanan barang (marhun) ditanggung oleh penggadai (rahin)".

Namun jika dalam jangka waktu tersebut telah berakhir dan pihak dari nasabah belum bisa melunasi hutangnya maka akan ada proses eksekusi jaminan atau eksekusi emas itu sendiri. Sebelum masa eksekusi tentunya nasabah sudah diberikan surat peringatan setelah sebanyak tiga kali dalam kurun waktu 30 hari setelah jatuh tempo sampai 90 hari setelah jatuh tempo. "Jika pihak nasabah belum bisa melunasi pembiayaan cicil emas selama masa pembiayaan, maka dari pihak bank memberikan peringatan sebanyak 3 kali dalam kurun waktu 30-90 hari setelah jatuh tempo. Apabila nasabah belum bisa melunasi juga maka jaminan atau emas yang ditangguhkan akan dieksekusi. Dalam pelaksanaan eksekusi jaminan, hasil penjualannya memperhitungkan sisa kewajiban nasabah (pokok, margin dan biaya lainnya yang menjadi beban nasabah) dengan ketentuan, apabila hasil eksekusi agunan lebih besar dari si kewajiban nasabah, maka selisih lebih tersebut dikembalikan kepada nasabah. Apabila hasil eksekusi agunan lebih kecil dari sisa kewajiban nasabah maka selisih kurang tersebut menjadi kewajiban nasabah".

Dapat disimpulkan bahwa dalam masa eksekusi jaminan bukan semata-mata menjual barang yang ditangguhkan, namun hal itu juga sudah dimusyawarahkan dan disetujui pihak nasabah. Jadi semua pihak tahu tentang eksekusi jaminan tersebut. Proses eksekusi tersebut sesuai dengan fatwa DSN MUI No: 25/DSN-MUI/III/2002 tentang Rahn yang salah satu isinya berbunyi "Apabila jatuh tempo, murtahin harus memperingatkan rahin untuk segera melunasi utangnya. Apabila rahin tetap tidak dapat melunasi utangnya, maka marhun dijual paksa/dieksekusi melalui lelang sesuai syariah".

Dari penjelasan di atas mengenai penerapan akad murabahah dan rahn yang digunakan dalam Produk Pembiayaan BSM Cicil Emas di Bank Syari'ah Mandiri Kantor Cabang Subang sudah sesuai dengan Fatwa DSN MUI, baik fatwa No:77/DSN-MUI/05/2010 tentang jual beli emas secara tidak tunai, fatwa DSNMUINo:04/DSN-MUI/IV/2000 tentang murabahah dan fatwa DSN MUINo: 25/DSNMUI/III/2002 tentang rahn.( Hasil Wawancara dengan Ibu Ratna Ayudini, Consumer Administration Staff Pada tanggal 22 Agustus 2019 di Bank Syari'ah Mandiri KCP Subang).

Dari penjelasan diatas mengenai penerapan akad murabahah dan akad rahn yang digunakan dalam produk pembiayaan BSM Cicil emas di Bank Mandiri Syari'ah KCP Subang sudah sesuai dengan syari'ah yang mengaturnya, baik itu dalm al-qur'an, alhadist, ijma, kaidah fiqih, maupun fatwa DSN MUI. 


\section{B. Implementasi Pembiayaan akad Murabahah dan Rahn pada Pembiayaan Cicil Emas di Bank Mandiri Syari'ah KCP Subang}

Berdasarkan hasil wawancara dengan Ibu Ratna Ayudini jenis murabahah yang dilaksanakan BSM KCP Subang adalah murabahah berdasarkan pesanan yang sifatnya mengikat kedua belah pihak. BSM KCP Subang hanya akan membeli barang berdasarkan pesanan nasabah sesuai dengan spesifikasinya, kemudian menjualnya kepada nasabah sebagai pemesan. Pembiayaan Produk Cicil Emas dapat digunakan seseorang apabila telah mengajukan permohonan untuk menjadi nasabah bank Syari'ah Mandiri KCP Subang, dengan ketentutan mengisi formulir permohonan, fotocopy KTP, fotocopy kartu identitas pegawai, slip gaji, fotocopy buku tabunganrekening gaji 3 bulan terakhir, standing intranction (bagi nasabah yang tidak payroll di BSM), NPWP dan surat pernyataan serta surat kuasa jual dari suami/istri (pembiayaan diatas lima puluh juta rupiah).

Berikut di bawah ini merupakan Proses Pembiayaan Cicil Emas di BSM KCP Subang sebagai berikut :

1. Nasabah mengajukan permohonan pembiayaan Cicil Emas dan bertemu dengan pelaksana penaksir (PP)/ Pelaksana Marketing Support (PMS)/ Asisten Analisis Mikro (AAM);

2. PP/PMS/AAM menerima dokumen permohonan pembiayaan Cicil Emas nasabah dan memeriksa kelengkapannya. Selanjutnya, menyerahkan seluru dokumen ke Officer Gadai OG)/ Acoount Ofiicer (AO)/ Kepala KLG (KKLG/ Kepala warung Mikro (KWM);

3. OG/AO/KKLG/KWM melakukan verifikasi income dan dokumen untuk selanjutnya dituangkan dalam NAP. Dalam penyusunan NAP, OG/AO/KKLG/KWM konfirmasi harga emas sebelum akad dan keputusan komite pembiayaan. NP kemudian diserahkan pada kepala unit (Kepala Cabang/ Kepala Capem) untuk diminta persetujuan;

4. Kepala unit meriview NAP dan memberikan keputusan;

5. OG/AO/KKLG/KWM menghubungi nasabah untuk akad pembiayaan;

6. Nasabah dan Bank melakukan akad pembiayaan;

7. OG/AO/KKLG/KWM menghubungi supplier emas (misal : Toko Emas/TE) untuk order emas nasabah;

8. TE mengantarkan emas ke BSM dan diterima oleh Loon admin serta diketahui oleh OM/OO (dual Control). Selanjutnya diserahkan ke penaksir/OG untuk dilakukan penilaian (penaksir) jaminan karena emas disimpan di bank;

9. OG/AO/KKLG/KWM membuat memo pencairan ke bagian operasional (petugas admin dan operation manager (OM)/ Operation Officer (OO);

10. Petugas admin mencairkan pembiyaan ke rekening nasabah;

11. Hasil penciran ditransfer ke rekening TE (Toko Emas) oleh Teller.( Buku Standar Operasional Prosedur (SOP) BSM KCP Subang, Subang, 22 Agustus 2019).

Berikut di bawah ini merupakan Syarat Pembiayaan Cicil Emas di BSM KCP Subang sebagai berikut :

\begin{tabular}{|c|l|c|c|c|}
\hline No & \multicolumn{1}{|c|}{$\begin{array}{c}\text { Jenis } \\
\text { Dokumen }\end{array}$} & Pegawai & Wiraswasta & Profesional \\
\hline 1 & $\begin{array}{l}\text { Asli formulir } \\
\text { permohonan } \\
\text { pembiayan } \\
\text { yang telah diisi } \\
\text { dan } \\
\text { ditandatangani }\end{array}$ & $\sqrt{ }$ & $\sqrt{ }$ & $\sqrt{ }$ \\
\hline 2 & $\begin{array}{l}\text { Fotocopy KTP } \\
\text { Nasabah dan } \\
\text { pasangan }\end{array}$ & $\sqrt{ }$ & $\sqrt{ }$ & $\sqrt{ }$ \\
\hline 3 & $\begin{array}{l}\text { Fotocopy kartu } \\
\text { keluarga (KK) }\end{array}$ & $\sqrt{ }$ & $\sqrt{ }$ & $\sqrt{ }$ \\
\hline 4 & $\begin{array}{l}\text { Fotocopy akte } \\
\text { nikah/cerai }\end{array}$ & $\sqrt{ }$ & $\sqrt{ }$ & $\sqrt{ }$ \\
\hline
\end{tabular}

EKSISBANK (Ekonomi Syariah dan Bisnis Perbankan), Volume 4, Nomor 2, Desember 2020 


\begin{tabular}{|c|c|c|c|c|}
\hline No & $\begin{array}{c}\text { Jenis } \\
\text { Dokumen }\end{array}$ & Pegawai & Wiraswasta & Profesional \\
\hline 5 & $\begin{array}{l}\text { Asli slip gaji/ } \\
\text { surat } \\
\text { keterangan } \\
\text { penghasilan } \\
\text { terkhir }\end{array}$ & $\sqrt{ }$ & - & - \\
\hline 6 & $\begin{array}{l}\text { Fotocopysurat } \\
\text { keputusan } \\
\text { pengangkatan } \\
\text { pegawai tetap } \\
\text { atau surat } \\
\text { ketengan } \\
\text { bekerja dengan } \\
\text { status tetap }\end{array}$ & $\sqrt{ }$ & - & - \\
\hline 7 & $\begin{array}{l}\text { Fotocopy } \\
\text { rekening } \\
\text { tabungan } \\
\text { gaji/rekening } \\
\text { usaha } \\
\text { (Giro/tabungan) } \\
\text { untuk nasabah } \\
\text { Golbertap } \\
\text { selama } 3 \text { bulan } \\
\text { terakhir dan } \\
\text { untuk nasabah } \\
\text { Non Golbertap } \\
\text { selama } 6 \text { bulan } \\
\text { terakhir }\end{array}$ & $\sqrt{ }$ & $\sqrt{ }$ & $\sqrt{ }$ \\
\hline 8 & $\begin{array}{l}\text { Surat } \\
\text { persetujuan dan } \\
\text { surat kuasa jual } \\
\text { dari suami/istri } \\
\end{array}$ & $\sqrt{ }$ & $\sqrt{ }$ & $\sqrt{ }$ \\
\hline 9 & $\begin{array}{l}\text { Fotocopy } \\
\text { NPWP (untuk } \\
\text { pembiayaan > } \\
\text { Rp. } 50 \text { juta) }\end{array}$ & $\sqrt{ }$ & $\sqrt{ }$ & $\sqrt{ }$ \\
\hline 10 & $\begin{array}{l}\text { Fotocopy surat } \\
\text { ijin usaa atau } \\
\text { ijin praktek }\end{array}$ & - & $\sqrt{ }$ & $\sqrt{ }$ \\
\hline 11 & $\begin{array}{l}\text { Surt ketengan } \\
\text { masih bekerja } \\
\text { (untuk jumlah } \\
\text {-> Rp. } 1 \text { juta) }\end{array}$ & $\sqrt{ }$ & - & - \\
\hline 12 & $\begin{array}{l}\text { SKDP, SIUP, } \\
\text { SITU, \& TDP }\end{array}$ & - & $\sqrt{ }$ & - \\
\hline
\end{tabular}

Produk Cicil emas di Bank Mandiri Syari'ah KCP Subang secara hukum menggunakan ketentuan dari DSN-MUI No:77/DSN-MUI/V/201 tentang Jual Beli Emas Secara tidak tunai yang ketentuannya telah dijelaskan sebelumnya. Sesuai dengan ketentuan fatwa tersebut, akad pembiayaan BSM cicil emas di BSM KCP Subang menggunakan akad murabahah, yaitu jual beli dimana bank sebagai pihak penjual dan nasabah sebagai pembeli dengan ketentuan margin sudah disepakati bersama.

Berikut adalah simulasi perhitungan pembiayaan cicil emas di BSM:

$$
\begin{aligned}
& \text { Harga barang Rp }=17.759 .560,- \\
& 710,382,- \text { x } 25 \text { gram } \\
& \text { Uang Muka } 20 \% \mathrm{x}=3.551 .912,- \\
& \text { 17.759.550,- }
\end{aligned}
$$

Jangka Waktu 2

\begin{tabular}{|c|c|c|}
\hline $\begin{array}{l}\text { Margin Bank } 18 \% \text { x } \\
\text { Rp 14.207.648,-- }\end{array}$ & & $\begin{array}{l}\text { 2. } 557.375,-\mathrm{x} 2 \\
\text { tahun }\end{array}$ \\
\hline 1 & - & pulan \\
\hline $14.750,-$ & $=$ & 19.322.390,- \\
\hline 19.322.390,- & & 805.099, \\
\hline
\end{tabular}

Tahun ( 24 bulan)

Pembiayaan $80 \% x=14.207 .648,-$
Rp 17.759.550,-

Bagi nasabah yang memperoleh pembiayaan BSM cicil emas dengan akad murabahah, besarnya margin yang diperoleh BSM akan tetap sampai periode pembiayaan berakhir, sehingga mempermudah nasabah dalam melakukan perencanaan keuangan, karena besar angsuran yang harus dibayar setiap bulannya sama sampai masa berakhirnya/jatuh tempo.

Sebagai contoh seorang nasabah datang ke Bank Syari'ah Mandiri Subang bermaksud mengajukan pembiayaan cicil emas jenis emas batangan dengan berat 25 Gram. Harga jual yang berlaku saat itu (Tanggal 14 Agustus 2019) Rp 710,382,- (Tujuh Ratus Sepuluh ribu rupiah tiga ratus delapan puluh dua)/gram. Ia akan mengangsur selama 2 (dua) tahun / 24 bulan dengan margin $18 \%$. Uang yang harus disiapkan oleh nasabah pada saat pengajuan dan angsuran yang harus dibayar oleh nasabah setiap bulannya, adalah sebagai berikut:

a. Biaya uang muka $20 \%$ dari harga barang.

b. Biaya administrasi $1 \%$ dari plafond pembiayaan.

EKSISBANK (Ekonomi Syariah dan Bisnis Perbankan), Volume 4, Nomor 2, Desember 2020 
c. Biaya Materai 2 Buah.

Aspek kehalalan barang yang diperjual belikan menjadi penting karena sebagimana difatwakan oleh DSN-MUI No:04/DSNMUI/IV/2000 tentang murabahah menyebutkan bahwa, "Barang yang diperjual belikan tidak diharamkan oleh syari'ah islam dan emas tidak termasuk barang yang dikategorikan aram, dengan demikian produk ini tidak bertentangan dengan fatwa DSNMUI.

Selain akad Murabahah, produk cicil emas juga menggunakan akad Rahn. akad rahn digunakan sebagai pengikatan agunan atau emas itu sendiri selama masa pencicilan emas berlangsung. Secara umum, pengertian gadai (rahn) yaitu menahan barang jaminan yang bersifat materi milik si peminjam (rahin) sebagai jaminan atas pinjaman yang diterimanya, dan barang yang diterima tersebut bernilai ekonomis, sehingga pihak yang menahan (murtahin) memperoleh jaminan untuk mengambil kembali seluruh atau sebagian utangnya dari barang yang digadaikan, bila pihak yang menggadaikan tidak dapat membayar utang pada waktu yang telah ditentukan maka jaminan tersebut akan dieksekusi. Namun, semua itu tentutnya sudah ada kesepakatan terlebih dahulu antara pihak bank dengan nasabah pada saat akad berlangsung.

Jika pihak nasabah belum bisa melunasi pembiaayaan cicil emas selama masa pembaiayan, maka dari pihak bank memberikan peringatan sebanyak 3 kali dalam kurun waktu 30-90 hari setelah jatuh tempo. Apabila nasabah belum bisa melunasi juga maka jaminan atau emas yang ditangguhkan akan bisa dilunasi juga maka jaminan atau emas yang ditangguhkan akan dieksekusi. Dalam pelaksanaan eksekusi jaminan, hasil penjualannya memperhitungkan sisa ekwajibannasaba (pokok, margin dan biaya lainnya yang menajdi beban nasbah) dengan ketentuan, apabila hasil eksekusi agunan lebih besar dari si kewajiban nasabah, maka selisih lebih tersebut dikembalikan kepada nasaba. Apabalia hasil eksekusi agunan lebih kecil dari sisa kewajiban nasabah maka selisih kurang tersebut menjadi kewajiban nasabah.

Dapat disimpulkan bahwa dalam masa eksekusi jaminan bukan semata-mata menjual barang yang ditangguhkan, namun hal itu juga sudah dimusyawahkan dan disetujui pihak nasabah. Jadi semua pihak tahu tentang eksekusi jaminan tersebut. Proses eksekusi tersebut sesuai dengan fatwa DSN-MUI No:25/DSN-MUI/III/2002 tentang rahn yang salah satu isinya berbunyi "apabila jatuh tempo, murtahin harus memperingatkan rahin untuk segera melunasi utangnya. Apabila rahin tetap tidak dapat meluanasi utangnya, maka marhun dijual paksa/dieksekusi melalui lelang sesuai syari'ah".

Dengan demikian dapat diambil kesimpulan, meskipun dalam pelaksanaan pembiayaan murabahah kepemilikan emas terjadi dua akad dalam satu transaksi, hal tersebut diperbolehkan karena prosedur terkait pembiayaan tersebut masih berada batas kewajaran dan selama akad dilakukan sudah sesuai dengan kesepakatan kedua belah pihak, tanpa ada unsur paksaan dan tidak terdapat dua harga dalam transaksi tersebut. Menurut peneliti, barang jaminan berupa emas batangan yang dibeli secara angsuran oleh nasabah tersebut kepemilikannya telah berpindah kepada nasabah saat terjadinya akad murabahah meskipun belum ada serah terima secara nyata, sehingga sah untuk menjadi barang jaminan. Bahwa pembiayaan cicil emas dengan menggunakan akad murabahah dan rahn tidak termasuk transaksi yang dilarang karena dalam transakasi pembiayaan cicil emas tersebut akad murabahah sebagai akad/perjanjian pokok, 
sedangkan akad rahn sebagai akad/perjanjian accesoir.

\section{Manfaat Pembiayaan akad Murabahah dan Rahn pada Pembiayaan Cicil Emas}

\section{a. Aman}

Maksud dari aman itu sendiri adalah emas dapat diasuransikan apabila menjadi kerusakan atau pencurian, emas tersebut bisa diganti.

\section{b. Menguntungkan}

Tarif yang kompetitif, maksudnya harga emas setiap tahunnya yang selalu meningkat menjadikan emas sebagai media investasi yang menguntungkan.

\section{c. Layanan yang Profesional}

Karena Bank Syari'ah Mandiri merupakan perusahaan terpercaya dengan kualitas layanan terbaik. Serta emas dapat diuangkan dengan cara dijual atau digadaikan.

Strategi pemasaran pembiayaan Bank Syari'ah Mandiri cicil emas yang dilakukan oleh Bank Syari'ah Mandiri KCP Subang adalah dengan menampilkan mutu dari produk tersebut. Sehingga dapat memenuhi kebutuhan masyarakat dan kebutuhan pasar sasaran. Mutu dari produk ini meliputi pemberian fasilitas dan kemudahan yang terdapat dala karakteristik produk, antara lain :

1. Emasnya bisa diasuransikan dan penawaran syari'ah dengan margin yang kompetitif;

2. Emas merupakan salah satu investasi yang mampu memproteksi kekayaan, khususnya untuk jangka panjang;

3. Produk ini dapat mewujudkan impian dan rencana dimasa mendatang;

4. Emas disimpan ditempat yang aman yaitu ruang khasanah

\section{KESIMPULAN}

Kesimpulan Berdasarkan berbagai penjelasan yang didapat dari penelitian yang dilakukan di Bank Mandiri Syari'ah Kantor
Cabang Pembantu Subang adalah sebagai berikut; Pelaksanaan akad murabahah dan rahn pada produk pembiayaan BSM Cicil Emas di Bank Syari'ah Mandiri Kantor Cabang Pembantu Subang terlihat dari skema Standar Prosedur Operasional (SPO), yaitu dilakukan dengan cara :

a. Dalam prosedur pelaksaan akad murabahah: nasabah mengajukan permohonan pembiayaan kepada bank. Kemudian pihak bank memeriksa kelengkapan dokumen permohonan pembiayaan cicil emas nasabah. Apabila pihak bank menyetujui permohonan pembiayaan tersebut pihak bank langsung menghubungi nasabah untuk melakukan akad pembiayaan. Setelah akad pembiayaan cicil emas tersebut dilakukan, kemudian bank (OG/AO/KWM) menghubungi supplier emas (Toko Emas/TE) untuk memesan emas nasabah. Setelah itu TE mengantar emas ke BSM, selanjutnya diserahkan ke penaksir /OG untuk dilakukan penilaian jaminan karena emas disimpan di bank.

b. Dalam prosedur akad rahn: Emas yang dijadikan objek pembiayaan disimpan dibank selama tenggang waktu 1-5 tahun dimana penyerahan barangnya dilakukan setelah cicilan nasabah lunas dikarenakan barangnya tersebut dijadikan jaminan oleh bank.

Penerapan akad pembiayaan murabahah dan akad rahn sudah selaras dengan ekonomi syari'ah. Keselarannya ini dapat dilihat dari landasan hukum yang mengatur akad murabahah maupun akad rahn pada produk pembiayaan cicil emas baik itu yang termaktub.

Manfaat Pembiayaan akad Murabahah dan Rahn pada Pembiayaan Cicil Emas. Pertama, Aman karena emas dapat diasuransikan apabila menjadi kerusakan atau pencurian, emas tersebut bisa diganti. Kedua 
Menguntungkan, karena tarif yang kompetitif, maksudnya harga emas setiap tahunnya yang selalu meningkat menjadikan emas sebagai media investasi yang menguntungkan. Ketiga layanan yang Profesional, karena Bank Syari'ah Mandiri merupakan perusahaan terpercaya dengan kualitas layanan terbaik. Serta emas dapat diuangkan dengan cara dijual atau digadaikan.

\section{Saran}

Saran-saran yang dapat penyusun berikan adalah sebagai berikut: Untuk Bank Syari'ah Mandiri KCP Subang

a. Diharapkan Bank Syari'ah Mandiri KCP Subang dapat mempertahankan nasabah dan meningkatkan jumlah nasabah dengan selalu menjaga kualitas pelayanan terbaik untuk nasabah.

b. Dapat menunjukan kepada nasabah bahwa Bank Syari'ah Mandiri KCP Subang telah melakukan operasional berdasarkan prinsip syari'ah.

c. Bank Syari'ah Mandiri KCP Subang diharapkan lebih sering mengadakan pelatihan untuk karyawan. Dalam rangka meningkatkan pengetahuan tentsng produk-produk. Melalui pelatihan tersebut agar dapat mengaplikasikannya sesuai dengan prinsip syari'ah.

\section{DAFTAR PUSTAKA}

Azmy, A. (2014). Evaluasi Kebijakan Pemerintah Dalam Menjaga Stabilitas Pertumbuhan Ekonomi Tahun 2013. Signifikan: Jurnal Ilmu Ekonomi, 3(1). https://doi.org/10.15408/sigf.v3i1.2064

Dwi Nurul Hasnawati. (2018). Analisis Pembiayaan Murabahah Cicil Emas Pada Bank Syariah Mandiri Cabang Pontianak. Jurnal NESTOR Magister Hukum, 3(3). https://jurnal.untan.ac.id/index.php/nesto r/article/view/29868

Fauziah, A., \& Surya, M. E. (2016). Peluang
Investasi Emas Jangka Panjang Melalui Produk Pembiayaan BSM Cicil Emas (Studi Pada Bank Syariah Mandiri KC. Purwokerto). Islamadina: Jurnal Pemikiran Islam, 16(1), 57-73.

Hatoli, H., \& Parwanti, W. (2020). Multiakad Murabahah Dan Rahn Pada Produk Logam Mulia Perspektif Hukum Ekonomi Syariah. Shar-E : Jurnal Kajian Ekonomi Hukum Syariah, 6(1), 25-32. https://doi.org/10.37567/shar-e.v6i1.14

Hendryadi, S. (2015). Metode Riset Kuantitatif Teori dan Aplikasi Pada Penelitian Bidang Manajemen dan Ekonomi Islam. Prenadamedia Group.

Hidayat, S. (2013). Penerapan Akuntansi Syariah Pada Bmt Lisa Sejahtera Jepara. Jurnal Dinamika Ekonomi \& Bisnis, 10(2).

https://doi.org/10.34001/JDEB.V10I2.83

Kasim, S. R. (2016). Pandangan Ekonomi Islam Tentang Investasi Murabahah Logam Mulia (Studi pada Cabang Pegadaian Syariah Istiqlal Manado). Jurnal Ilmiah Al-Syir'ah, 12(1). https://doi.org/10.30984/as.v12i1.276

Lestari, R. (2020). Pelaksanaan Bagi Hasil Simpanan dan Pembiayaan Mudharabah Di BMT Al-Amanah Cabang Subang. EKSISBANK: Ekonomi Syariah Dan Bisnis Perbankan, 4(1), 32-38. https://doi.org/10.37726/ee.v4i1.92

Maulidiyah, I., \& Susyanti, J. (2017). Analysis Of The Influence Of Funding Murabahah, Mudharabah, Musyarakah, And Rahn (Pawning) Of Gold Toward Net Profit Of PT Bank Syariah Mandiri (BSM), Tbk. Jurnal Ilmiah Riset Manajemen, $\quad 6(2)$. http://riset.unisma.ac.id/index.php/jrm/ar ticle/view/140

Meirani, R. A., Damiri, A., \& Jalaludin, J.

EKSISBANK (Ekonomi Syariah dan Bisnis Perbankan), Volume 4, Nomor 2, Desember 2020 
(2020). Penerapan Akad Murabahah pada Produk MULIA di Pegadaian Jalancagak Menurut Perspektif Ekonomi Syariah. EKSISBANK: Ekonomi Syariah Dan Bisnis Perbankan, 4(1), 60-68. https://doi.org/10.37726/ee.v4i1.69

Mulyani, F., Fauziah, E., \& Surahman, M. (2017). Analisis Fatwa DSN MUI No.77 / Dsn-Mui / V / 2010 Tentang Cicil Emas Akad Murabahah Pada Produk Cicil Emas Di Bank Syariah Mandiri (BSM) Kcp Surapati. Prosiding Keuangan Dan Perbankan SyariahSyariah, 3(2), 518521.

http://karyailmiah.unisba.ac.id/index.php /hukum_ekonomi_syariah/article/view/7 175

Rahman, N. M., Sudarno, S., \& Roziq, A. (2018). Perlakuan Akuntansi Pembiayaan Gadai dan Cicil Emas PT Bank Syariah Mandiri Jember. E-Journal Ekonomi Bisnis Dan Akuntansi, 5(1), 53. https://doi.org/10.19184/ejeba.v5i1.7877

Renny Tri Setiani. (2018). Penerapan Akad Murabahah Dalam Produk Gadai Emas Bank Syariah Mandiri (BSM) Di Kantor Cabang Sleman. Jurnal Kajian Hukum, $3(2)$.

Rival, V., \& Ismail, R. (2013). Islamic Risk Management for Islamic Bank. PT. Gramedia Pustaka Media.

Seroja, S., \& Iqbal, M. (2020). Transaksi Pembelian Emas Non Riil Di PT. Pegadaian Syariah KCP. Darussalam Dalam Perspektif Akad Ba'i AlMuqayyad (Studi Tentang Cicilan Emas Dan Konsekuensinya Pada Tabungan
Emas). Dusturiyah: Jurnal Hukum Islam, Perundang-Undangan Dan Pranata Sosial, $\quad 10(1), \quad 2020$. https://doi.org/10.22373/dusturiyah.v10i 1.7501

Sihono, T., \& Yusof, R. (2012). Bauran Kebijakan Moneter Dan Makroprudensial Bank Indonesia Semenjak Maret 2011 Hingga Maret 2012. Jurnal Economia, 8(1), 97-115. https://doi.org/10.21831/economia.v8i1. 824

Sugiyono. (2018). Metode Penelitian Kuantitatif, Kualitatif, dan $R \& D$. Alfabeta.

Tanuwidjaja, W. (2009). Cerdas Investasi Emas. Medpress.

Ulfah, F. U. (2020). Harga \& Buyback Emas Antam Hari Ini, 22 Mei 2020 - Market Bisnis.com. Https://Market.Bisnis.Com/. https://market.bisnis.com/read/20200522 /235/1243646/harga-buyback-emasantam-hari-ini-22-mei-2020-

Yaqin, A. A. (2019). Strategi Pemasaran pembiayaan cicilan emas di BSM KCP Dramaga. Amwaluna: Jurnal Ekonomi Dan Keuangan Syariah, 3(2), 229-237. https://doi.org/10.29313/amwaluna.v3i2. 4586

Yustina, A. (2013). Investasi Emas untuk Ibu Rumah Tangga. Grup Khitah Publishing.

Zaenuri. (2014). Konsep Pembiayaan Pemilikan Emas Pada Perbankan Syariah (Studi Di Bank Mandiri Syariah Semarang). Jurnal At-Taqaddum, 6(2). 